Catharina Nyström Höög

Professor i svenska språket

Högskolan Dalarna och Uppsala universitet

\title{
Värdegrundstexter - ett nytt slags uppdrag för klarspråksarbetet?
}

\begin{abstract}
This article presents a relatively new and evolving genre at public authorities, the platform of values (värdegrund). The platform of values is presented as part of a changing discourse, where presenting the public authority in question in a positive manner is getting increasingly more important. In this respect, the platforms of values resemble marketing texts, but they are also regarded as tools for governing. Since the texts articulate an expected manner of behaviour, for example that the authority is efficient and committed, they offer a subtle way of imposing a code of conduct on employees. The main focus in the article is on the relation between plain language norms and the genre of platform of values. Textual analysis of three platforms of values reveals that there are not many problems of comprehensibility, but that the level of lexical abstraction might pose a problem for readers. There are also other problems related to the platforms of values. They increase the amount of texts and genres within the public authorities, which increases costs in time and money. They also tend to be unclear communicatively, and might gloss over problems of behaviour, since they are written in a declarative mode. From a language policy perspective, they offer an opportunity to discuss the boundaries of plain language, and possible sharpen the concept of plain language practice.
\end{abstract}

\section{Sammandrag}

Artikeln presenterar en ny och framväxande genre vid svenska myndigheter, nämligen värdegrunder. Värdegrundstexterna ses här som en del $i$ en förändrad diskurs, där det blir allt viktigare att presentera den egna myndigheten positivt. I så måtto liknar värdegrunderna marknadsföringstexter, men de kan också betraktas som styrinstrument. Eftersom texterna artikulerar ett förväntat beteende, till exempel att myndigheten är effektiv och engagerad, erbjuder de ett subtilt sätt att reglera beteende hos de anställda. Artikelns fokus är värdegrundstexternas relation till klarspråksnormen. Analyser av tre värdegrundstexter visar att texterna knappast innebär begriplighetsproblem, även om de många abstrakta orden kan innebära problem. Andra problematiska aspekter med värdegrunderna är att de bidrar till att utöka myndigheternas textrepertoar, och därmed kostar arbetstid och pengar. De har också en tendens att vara kommunikativt oklara, och kan i värsta fall dölja problem, eftersom de är skrivna som påståenden (vi är effektiva) snarare än som uppmaningar (vi ska vara effektiva). 
Ur språkvårdsperspektiv innebär texterna en möjlighet att diskutera vilka texter som ska omfattas av kravet på klarspråk, och kan på så sätt möjligen bidra till att begreppet klarspråk blir snävare och skarpare.

Det svenska klarspråksarbetet får ökat stöd av språklagen (SFS 2009:600). Det är särskilt den elfte paragrafen som har betydelse för klarspråksarbetet: "Språket i offentlig verksamhet ska vara vårdat, enkelt och begripligt”. Enligt Språkrådets uttolkning av språklagen innebär paragrafen en skärpning av klarspråkskravet, eftersom kravet gäller all offentlig verksamhet och "inte bara den som bedrivs av förvaltningsmyndigheter" och även sådan kommunikation som sker mellan myndigheter och myndighetsinternt (Språkrådets uttolkning). En angelägen fråga för alla som arbetar med klarspråk är vilka texter som omfattas av språklagens krav. Utifrån det svenska klarspråksarbetets tradition kan man säga att vissa texter getts prioritet framför andra. Det gäller för det första författningstexter, utifrån argumentet att sådana texter kan betraktas som första led i en kedja där innehållet bearbetas många gånger, och att "förstatexten" därför behöver vara lättläst för att spara tid och pengar (jfr Nyström Höög, Söderlundh \& Sörlin 2012 ff.). För det andra gäller det texter som direkt vänder sig till allmänheten, som individer eller kollektiv: beslutstexter, broschyrer, informationsblad och på senare tid även webbplatser (se t.ex. På väg mot ett bättre myndighetsspråk 2001).

Inom den offentliga verksamheten finns dock många texter som inte hamnar inom någon av dessa, av klarspråksverksamheten prioriterade kategorier. Den här artikeln tar sig an en sådan kategori, nämligen det slags policytexter som oftast kallas värdegrundstexter, och som har till syfte att reglera människors beteende gentemot varandra, inom eller utom den egna myndigheten. Värdegrundstexter är visserligen en kategori som är svår att avgränsa mot andra typer av policytexter, men i en systematisk genomgång av 179 svenska myndigheters webbplatser (Nyström Höög 2014) har jag kunnat identifiera tydliga mönster i de texter jag vill kalla värdegrunder. Ofta centreras de till exempel kring tre värdeord. Benämningarna på texterna skiljer sig dock åt; jag har hittat både värdegrund, värden, värdeord, nyckelord och ledord. Värdegrundstexterna varierar inte bara sinsemellan, utan har också tydliga likheter med myndigheters visioner (se t.ex. Waaranperä 2013). Visionstexter och värdegrundstexter har det gemensamt att de gärna har en tydlig avsändare som kan ge tyngd åt texten och att de har många positiva värdeord. Andra policytexter vid svenska myndigheter, till exempel kommunikationspolicy (jfr Fredriksson \& Pallas 2013), skiljer sig från visions- och värdegrundstexter i och med att de anknyter konkret till en bestämd del av verksamheten. Värdegrundstexterna kan sammanfattande sägas vara en snabbt framväxande men svagt avgränsad kategori av texter. I den här artikeln vill jag presentera de svenska myndigheternas värdegrunder, och har avgränsat mitt intresse till de texter som explicit har rubriken "värdegrund". Efter en inledande presentation av företeelsen - varför texterna finns och varför de fått just denna benämning - övergår jag till att diskutera värdegrundstexternas relation till andra myndighetstexter och ser dem som uttryck för en delvis förändrad myndighetsdiskurs, där synliggörandet av den egna myndigheten är central. Avslutningsvis presenteras tre exem-pel på värdegrundstexter i en utförligare analys, varefter eventuella klarspråksproblem i texterna kommenteras. 


\section{Varför finns värdegrundstexter vid svenska myndigheter?}

Den offentliga förvaltningen, inte bara i Sverige utan i hela västvärlden, har genomgått dramatiska förändringar under de senaste 50 åren. Förändringar i den offentliga förvaltningen har gått från att vara interna, och ganska tekniska, angelägenheter, till att vara allmänpolitiska frågor. Inte sällan lanseras idag omläggningar i administrativa angelägenheter som efterlängtade nyheter. Pollitt \& Bouckaert (2011), som studerat reformer i den offentliga förvaltningen, identifierar tre stora vågor av organisationsförändringar från mitten av 1960-talet och fram till idag. Sverige har först och främst påverkats av den andra av dessa, i vilken många administrationer ställt om till mera affärsliknande system med högre krav på ekonomisk effektivitet. Sverige, och flera andra länder i västvärlden, genomförde på 1980-talet en rad olika förändringar som brukar samlas under benämningen New Public Management (NPM). Pollitt \& Bouckaert menar dock att förändringarna inte enbart handlar om införande av NPM, utan om att flera olika paradigm konkurrerar. ${ }^{1}$ Framträdande drag i den svenska förvaltningens omorganisation har varit satsning på e-förvaltning, transparens och öppenhet i förvaltningen samt resultatstyrd ekonomi. Ett inslag i den förändrade förvaltningen är reglering av personalens beteende (Pollitt \& Bouckaert 2011, s. 42). Sådan reglering tjänar två syften, dels att de anställda ska uppföra sig så att de arbetar i den eftersträvade andan, dels att bevara, eller återställa, allmänhetens förtroende för förvaltningen. Ett förslag till förklaring till värdegrundsdokumentens uppsving i det svenska samhället finns hos Rehnberg (2014). Hon ser intresset för värdegrundsarbete som ett uttryck för ett nytt slags ledarskap, där en central uppgift för ledaren är att påverka uppfattningar hos de anställda. I denna nya arbetsordning förväntas medarbetare vara kreativa och delaktiga, men organi-sationsledningar har också ett "behov av att försäkra sig om att ingen avviker från den utstakade vägen" (Rehnberg 2014, s. 30). I det perspektivet blir värdegrundstexterna viktiga styrinstrument.

Ordet värdegrund är hämtat från skolans värld. Det dyker upp första gången i ett förarbete till 1994 års läroplan, Lpo 94 (SOU 1992:94). Och när läroplanen presenteras har den ett avsnitt som heter "Skolans värdegrund och uppgifter" (Lpo 94, s. 14 ff.). Ganska snart dyker ordet också upp i sammanhang som inte har koppling till skolans värld. Genom sökningar i Språkbankens korpusverktyg (KORP) ser man att ordet används om verksamheter utanför skolan några år in på 2000-talet. År 2006 finns till exempel ett belägg som rör "den värdegrund som Alingsås kommun står för" (GP). I KORP är det också möjligt att söka i Svensk författningssamling (SFS). Också där rör de flesta träffarna på ordet värdegrund utbildningsvärlden, men redan år 2001 finns ordet i socialtjänstlagen ${ }^{2}$.

$\mathrm{Idag}^{3}$ har många olika aktörer en egen formulerad värdegrund: myndigheter på statlig, landstingskommunal och kommunal nivå, föreningar och frivilligorganisationer samt kom-

\footnotetext{
${ }^{1}$ Ett intressant resonemang hos Pollitt \& Bouckaert (2011, s. 12 f.) går ut på att New Public Managements betydelse kommit att övervärderas delvis för att de flesta länder som infört systemet är engelskspråkiga, och att forskare och politiker i stora delar av världen företrädesvis läser engelska, vilket gör att NPM blivit dominerande i diskursen om administrationsförändringar.

2 I socialtjänstlagens femte kapitel (SFS 2001:453) står att “Socialtjänstens omsorg om äldre ska inriktas på att äldre personer får leva ett värdigt liv och känna välbefinnande (värdegrund)”.

${ }^{3}$ En google-sökning på ordet värdegrund i juli 2013 gav nära 9 miljoner träffar. Resonemanget i detta stycke baseras på en genomgång av delar av de träffarna.
} 
mersiella företag. Deras värdegrundstexter varierar kraftigt i fråga om utformning. Vissa texter är långa. Några är tryckta i påkostade dokument med bilder, andra är bara ett litet stycke text eller några punkter med särskilt slagkraftiga ord. I vissa fall uttrycks värdegrunden av anställda som talar utifrån valda nyckelbegrepp, och det är alltså svårt att kort sammanfatta hur en värdegrund typiskt ser ut. Mina allmänna slutsatser i den här artikeln bygger på läsning av ett antal värdegrunder, men jag har valt tre olika värdegrunder som här får fungera som exempel, från skolan, Socialstyrelsen och Polisen ${ }^{4}$.

\section{Ordet värdegrund}

Under hösten 2013 inträffade två händelser i Sverige som aktualiserade värdegrundsbegreppet. Den första var ett misshandelsfall vid en internatskola (se t.ex. "Internatelever brändes med strykjärn”, Svenska Dagbladet 27/8 2013). Skolinspektionen beslutade att stänga skolan, och Skolinspektionens generaldirektör sade i en presskonferens att misshandelsfallet var ett uttryck för "den kultur och den värdegrund" som råder på skolan ("Skolinspektionen stänger Lundsberg”, Dagens Nyheter 29/8 2013). Ordet värdegrund förekommer inte i det beslut som Skolinspektionen skriver i ärendet (Skolinspektionens beslut om Lundsbergs skola), men citatet visar att värdegrund är ett ord som vi idag använder i allmänspråket för att hänvisa till regler för beteende.

Den andra händelsen var avslöjandet att ett svenskt polisdistrikt registrerat romer utifrån etnicitet, en händelse som står i stark motsättning mot Polisens värdegrundsarbete. Ungefär samtidigt som dessa två händelser inträffade kom arbetsgivare och fackföreningar inom vård och omsorg överens om en ny "etisk plattform" ("Etisk plattform på plats ..."). Det går att tolka bruket av uttrycket etisk plattform som ett tecken på att värdegrundens tid är förbi. Andra tecken på detsamma är att alternativa texter dyker upp; hos Försäkringskassan förekommer exempelvis kundlöften (Försäkringskassan.se). Ordet värdegrund har alltså, på kort tid, tömts på betydelse. Den korta livstiden i offentligheten - utanför skolan - gör att ordet värdegrund i sig förtjänar en språkvetenskaplig studie som kan ge en inblick i hur ord introduceras, populariseras och försvinner.

Den typ av uppförandereglerande text som värdegrundstexterna representerar visar dock inga tecken på att förlora i betydelse. Texternas befästa ställning är ett gott skäl att göra dem till föremål för studium ur språkvetenskapligt perspektiv; de är intressanta både eftersom de förändrar myndigheternas textrepertoar och eftersom de har en annan relation mellan mottagare och avsändare än de flesta andra myndighetstexter och därmed möjligen erbjuder nya utmaningar för myndigheternas arbete med klarspråk.

\section{Värdegrundstexterna i relation till andra myndighetstexter}

Den här artikeln fokuserar tre olika värdegrundstexter. Alla tre representerar riksomspännande verksamheter. Den svenska skolan är visserligen en kommunal organisation, men läroplanen

\footnotetext{
${ }^{4}$ Fram till den 31 december 2014 fanns det 21 regionala polismyndigheter i Sverige, med rikspolisstyrelsen som central förvaltningsmyndighet. Den värdegrund som diskuteras här var gemensam för alla de regionala polismyndigheterna och har hämtats från den gemensamma webbplatsen.
} 
är nationell. Socialstyrelsen och Polisen är stora statliga myndigheter, vilkas verksamhet kan beröra många människor. Så till vida liknar de tre texterna varandra. Sett till textutformningen är dock skillnaderna mera påfallande.

Texten "Skolans värdegrund och uppdrag” är lång - 1661 löpord. Texten ligger som ett avsnitt i dokumentet Läroplan för grundskolan, förskoleklassen och fritidshemmet (Lgr 11), en text som är närmare trehundra sidor lång. Socialstyrelsens värdegrund kan laddas ned från webbplatsen (Socialstyrelsen.se) där den ligger som pdf-fil. Den finns också publicerad som broschyr, med genomtänkt grafisk formgivning. Värdegrundstexten ramas in inte bara av bilder utan också av generaldirektörens inledande förord - med en bild på ledningsgruppen på motstående sida - samt av en avslutande text som vägleder den läsare som vill veta mera om värdegrunden till rätt instans. Texten är alltså tydligt kopplad till personer som ses som avsändare. När de omgivande metatexterna räknas bort omfattar värdegrundstexten strax under 500 löpord. Polisens värdegrund, slutligen, kan nås från den myndighetsgemensamma webbplatsen (Polisen.se/om-polisen/uppdrag-och-mal). Där finns värdegrundstexten återgiven i sin helhet under rubriken "Polisens värdegrund". Texten är placerad på en grafiskt markerad platta och föregås av en kort metatext som redogör för hur värdegrunden vuxit fram. Den som vill ha ytterligare information kan klicka vidare till nästa nivå "Fakta om Polisens värdegrund" och får då veta varför Polisen ska ha en värdegrund och vem som ska använda den. Själva värdegrundstexten är mycket kort, 65 löpord, och de tre centrala värdeorden är tydligt framhävda:

Polisens uppdrag är att öka tryggheten och minska brottsligheten. Vi genomför vårt uppdrag professionellt och skapar förtroende genom att vara:

- Engagerade - med ansvar och respekt. Vi tar ansvar för vår uppgift och värnar om allas lika värde.

- Effektiva - för resultat och utveckling. Vi är fokuserade på resultat, samarbete och ständig utveckling.

- Tillgängliga - för allmänheten och för varandra. Vi är hjälpsamma, flexibla och stödjande.

Polisens värdegrund är den av de valda texterna som är mest lik den kommersiella världens s.k. mission statements, och som tydligast för tanken till värdegrundstexten som en del i varumärkesbyggande. ${ }^{5}$

Värdegrundstexterna ingår i en repertoar av texter som styr och reglerar verksamhet vid myndigheter. Alla myndigheter i Sverige styrs av regeringsformen. I den nionde paragrafen

\footnotetext{
${ }^{5}$ Som ett exempel kan man jämföra Polisens kortfattade värdegrund med kaffekedjan Starbucks: "Our mission: to inspire and nurture the human spirit - one person, one cup and one neighborhood at a time". Hämtat från Your dictionary.com. Uppslagsordet Examples of Mission Statements.
} 
(SFS 1974:152) stadgas att förvaltningsmyndigheter ska "beakta allas likhet inför lagen" samt iaktta "saklighet och opartiskhet".

Varje myndighet får också ett årligt regleringsbrev från regeringen, där uppdraget för det aktuella året anges. I Polisens regleringsbrev för 2013 står det till exempel att

Förtroendet för Polisen ska vara högt och Polisen ska vara synlig och tillgänglig i hela landet. Polisens verksamhetsresultat ska förbättras.

Regleringsbrevet berör alltså även den bild som allmänheten ska få av Polisen och dess verksamhet. Värdegrunden kan i det avseendet betraktas som ett slag uttolkning av vad Polisen genom regleringsbrevet är förelagd. Texten i värdegrunden kan ses både som ett krav på polisens personal, och som ett löfte från polisen till medborgarna.

Skolan skiljer sig från Polisen och Socialstyrelsen, eftersom den är en kommunal organisation. Skolan styrs av skollagen (SFS 2010:800) och av skolförordningen (SFS 2011:185). Samtliga myndigheter som behandlas här styrs också av förvaltningslagen (SFS 1986:223). Vilka texter som styr myndigheterna kan tyckas självklart, men är viktigt att reflektera över om man vill anlägga klarspråkssynpunkter på värdegrundstexterna och andra policytexter. Texterna ingår i vad man kan kalla för intertextuella kedjor (se t.ex. Winther Jørgensen \& Phillips 2011, s. 77). I grunden för verksamheten finns lagtexter, som är juridiskt reglerande, men som vanligtvis inte används för att visa myndighetens verksamhet för allmänheten. Värdegrundstexterna är tvärtom avsedda att ge en bild av myndighetens verksamhet, men är inte juridiskt bindande. När det står i Polisens värdegrund att "vi tar ansvar för vår uppgift och värnar om allas lika värde" är det bara indirekt Polisen som är avsändare. Uppdraget att värna om allas lika värde finns i regeringsformen ${ }^{6}$ (SFS 1974:152).

Innehållsmässigt innebär alltså inte värdegrundstexterna några nyheter. Vad tillför de då till myndigheternas textvärld? Ja, de vänder sig till en annan målgrupp än de flesta andra myndighetstexter, nämligen primärt till myndighetens egna medarbetare, och i någon mån till myndighetens kunder, klienter eller brukare. Värdegrundstexten innehåller som nämnts inga juridiskt bindande formuleringar om myndighetens åtaganden gentemot medborgaren, men är ofta väl synlig på myndighetens webbplats. För att förstå värdegrundstextens plats i myndighetens textvärld krävs alltså viss organisationskunskap. Ur klarspråksperspektiv kan man därför fråga sig vad mängden texter - exempelvis på webbplatsen - har för inverkan på medborgarens möjligheter att förstå och tolka myndigheten.

Myndigheternas olika texter påverkar varandra. Från klarspråksarbetet vet vi att lagspråkets formuleringar tenderar att hänga kvar i andra texter som bygger på lagen; det är ju ett huvudargument för att satsa på klarspråksinsatser för författningstexterna. I fallet med policytexter skulle vi behöva klarlägga relationerna mellan texterna, för att veta var - och om - det är relevant med klarspråksinsatser. Ett pilotprojekt i den andan har genomförts av Koskela (2013), som studerat intertextuella och interdiskursiva drag i olika försäkringsbolags

\footnotetext{
${ }^{6}$ Regeringsformen är en av Sveriges fyra grundlagar, och den som främst formar statskicket. Där anges hur landet ska styras, vilka demokratiska rättigheter vi har och hur den offentliga makten ska fördelas.
} 
kommunikationsstrategier. Hon konstaterar där att strategitexterna har labil genrekaraktär, vilket skulle kunna förklaras av att det är en genre i framväxt. Liknande resultat skulle kunna väntas från en systematisk genomgång av värdegrundstexter. Vi kan typifiera de här texterna utifrån den verksamhet de ingår $\mathrm{i}$, men knappast förvänta oss homogenitet $\mathrm{i}$ textutformningen. ${ }^{7}$

\section{Värdegrundstexterna som uttryck för en förändrad myndighetsdiskurs}

Åtminstone Polisens värdegrund liknar texter som hör hemma i en marknadsdiskurs, och klart är att värdegrundstexterna på flera punkter avviker från det som kan anses som typiskt myndighetsspråk, alltså ett formellt och stelt språkbruk med starka inslag av fackordförråd (Språket i lagar och andra författningar 1967). De kan därmed ses som uttryck för en pågående avbyråkratisering av de svenska myndigheternas språkbruk. Sarangi \& Slembrouck (1996) har visat hur byråkrati - här i betydelsen myndigheters organisation och verksamhet och byråkratiskt språk kan förstås som storheter oberoende av varandra. Ett exempel på att myndigheters språkbruk rör sig i riktning mot ett mindre byråkratiskt uttryckssätt finns i reklamliknande information. I Sverige har vi kunnat se sådana exempel på Försäkringskassans webbplats, med påfallande kamratligt tilltal (Hanell 2012). Det motsatta förhållandet, att traditionellt icke-byråkratisk verksamhet närmar sig ett byråkratiskt språkbruk, kan exemplifieras med en tilltagande dokumenthantering och formulärkrävande anställningsförfaranden inom skolor och högskolor.

Med utgångspunkt i processerna byråkratisering och avbyråkratisering diskuterar Sarangi \& Slembrouck (1996) konsekvenserna för myndighetsspråket. Den logiska följden av att det byråkratiska språket kan förändras och förenklas är ju att en byråkrati utan byråkratiskt språk är tänkbar (1996, s. 9). I själva verket formulerar också principerna för klarspråksarbete (och det engelskspråkiga arbetet med Plain Language) en önskan om att det byråkratiska språket ska förändras och ersättas av ett mera lättbegripligt språk. Man kan förstå denna önskan utifrån den historiska kontext där klarspråksidéerna vuxit fram, nämligen i en myndighetskultur där fokus har legat på lagar och förordningar, på att hantera ärenden mellan medborgare och myndighet. Men dagens myndighetskultur ser annorlunda ut. Det framgår exempelvis av två svenska undersökningar av olika typer av dokument.

Fredriksson \& Pallas (2013) har gjort en genomgång av 173 nationella svenska förvaltningsmyndigheters policydokument för kommunikation. De har undersökt vilka principer som styr arbetet med kommunikation. Utifrån fyra typer av principer - ryktbarhetens, det civilas, marknadens och produktionens - kartlägger de myndigheternas dokument. Slutsatsen blir att den dominerande principen är ryktbarhetens princip. Denna princip beskriver Fredriksson \& Pallas (2013, s. 11, efter Boltanski \& Thévenot 2006) som

en önskan att bli sedd, eftertraktad, uppmärksamhet, anseende, image, varumärke, att vara betydelsefull, där "celebriteter" - i dess vidaste bemärkelse - betraktas som kvalificerade

\footnotetext{
${ }^{7}$ Jfr Ledin \& Selander (2003, s. 108 ff.) som konstaterar att genrebegreppet har begränsat förklaringsvärde för textutformning.
} 
aktörer. Det är en princip som kommer till uttryck i påståenden som "Vår sida på Facebook har dubbelt så många följare som alla andra tillsammans”.

Att ryktbarhetens princip fått så stort genomslag i svenska myndigheters kommunikationspolicyer är möjligen ingen överraskning med tanke på att många svenska myndigheter finns på Facebook och andra sociala medier (jfr Söderlundh \& Sörlin 2014). Helt oproblematiskt är det däremot inte, särskilt inte ur klarspråksperspektiv. Det civilas principer, formulerade som kommunikationsprinciper där medborgare och kollektiva intressen är legitima aktörer och som vilar på "regler, lagstiftning, den allmänna viljan, gemensamma mål, delaktighet, rättigheter och skyldigheter" (Fredriksson \& Pallas 2013, s. 11), är i betydligt större utsträckning förenliga med vad som kan uppfattas som klarspråksverksamhetens kärna: strävan efter myndighetstexter skrivna på ett vårdat, enkelt och begripligt språk.

Andra texter som fungerar som verktyg i synliggörandet är myndigheternas formulering av sina visioner. Svenska myndigheters visionstexter har studerats av Waaranperä (2013) som undersökt 186 myndigheters hemsidor, vilket uppskattas till 40 procent av Sveriges myndigheter (2013, s. 2). Att hon valt just hemsidan som utgångspunkt för undersökningen är inte oviktigt, eftersom den kan sägas vara ett av de viktigaste uttrycken för den synliga myndigheten. När visionen publiceras på hemsidan blir den en tydlig signal om myndighetens strävan. Waaranperä finner att 91 av de undersökta myndigheterna har formulerade visioner. Hon karaktäriserar dem som "symbolladdade och värdebemängda" (2013, s. 3) och drar slutsatsen att myndigheterna genom sina visioner vill "gestalta sitt arbete, både för medborgare och beslutsfattare - men också för anställda - i syfte att förklara, tydlig- och synliggöra eller rentav motivera sin verksamhet" (2013, s. 2).

Också värdegrundstexter finns ofta tillgängliga på myndigheternas webbplatser, dock är de inte lika frekventa som visionstexter (Nyström Höög 2014). ${ }^{8}$ För både värdegrunder och visioner gäller att de fungerar som markörer av myndighetens kvalitet, utåt mot webbplatsanvändare, men även som utgångspunkt för diskussioner om mål, strategier och arbetsmiljö inåt, mot de anställda. Waaranperä resonerar om hemsidans betydelse (efter Augustsson 2004) att det finns en tendens att hemsidespresentationen hamnar närmare "hur man vill vara än hur man är” (2013, s. 3). Det gäller också de webbplatspublicerade dokumenten i sig, och detta faktum gör att det finns anledning att problematisera förekomsten av policydokument av olika slag.

I en artikel om policydokument och handlingsplaner mot diskriminering vid brittiska universitet, med den talande titeln "You end up doing the document rather than doing the doing”, skriver Ahmed (2007) om vikten av att antidiskrimineringsdokumenten följs upp, eftersom det annars är omöjligt att förstå hur de omsätts till handling. Artikelns fokus ligger på hur texterna, som universiteten enligt lag är ålagda att ha, kan komma att tas som intäkt för att situationen redan är tillfredsställande. Det finns en risk att värdegrundstexterna fungerar på liknande sätt. Det är fäst på pränt att Polisen redan är engagerad och främjar allas lika värde.

\footnotetext{
${ }^{8}$ Detta förhållande kan möjligen förklaras med att värdegrunderna tydligare än visionerna riktas inåt mot myndigheten. Det återstår dock att undersöka hur värdegrunder publiceras och används i myndigheternas dagliga arbete.
} 
Det finns inget i textens formulering som inbjuder anställda att förhålla sig till formuleringen och fråga sig hur man ska nå fram till den situation som värdegrundstexten beskriver. På så sätt kan dokumenten snarare dölja missförhållanden än bidra till att lösa upp dem.

I Sverige pågår en avbyråkratisering av myndigheternas kommunikation. I och med att typer av texter tillkommer som har som sin främsta uppgift att göra myndigheten synlig ökar också påverkan från marknadsföringsdiskurser. Värdegrundstexterna bär spår av båda dessa pågående förändringar. De avviker alltså på centrala punkter från traditionella myndighetstexter. Klarspråksarbetet tar sikte på att förändra svårbegripligt myndighetsspråk, men inte på att förändra myndigheternas språk som sådant - om dessa två företeelser nu i enlighet med Sarangi \& Slembrouck (1996) kan ses som skilda från varandra. Frågan är då om värdegrundstexterna, utifrån rent språkliga utgångspunkter, är relevanta att göra till föremål för klarspråksinsatser.

\section{Värdegrunderna som texter}

Trots att de svenska myndigheternas värdegrunder är varierade i fråga om utformning finns det vissa gemensamma mönster. Ett påfallande drag i de granskade värdegrunderna är avsaknaden av markerad textbindning i form av satskonnektion. Vare sig texterna är uppställda som Socialstyrelsens (delvis i punktform) eller som skolans (i löptext) saknas sådana bindningsmarkörer i stort sett helt. I de textformade kompenseras inte heller för avsaknaden av explicit markerad konnektion med exempelvis tät temaupprepning eller långa meningar (Nyström 2001, s. 100 ff.). Man får helt enkelt dra slutsatsen att värdegrunderna inte är avsedda att läsas som sammanhängande texter, utan snarare som listor med underförstådd additiv bindning. Det är bara i den jämförelsevis långa värdegrunden i skolans läroplan som avsaknaden av textbindning rent lästekniskt blir ett problem.

Ett annat gemensamt drag är att texterna är abstrakta på ordnivå, och har ganska många långa ord. Liksom de visionstexter Waaranperä undersökt kan de karaktäriseras som "symbolladdade och värdebemängda". Vanliga ord i både Polisens och skolans värdegrund är ansvar och utveckling, medan viktiga hör till de vanligare innehållsorden i Socialstyrelsens värdegrund. Ska man söka efter en genomgående tankefigur i texterna så är ansvar en central sådan.

Graden av konkretion i texterna har relevans för klarspråksperspektivet (jfr Nyström Höög 2012, s. 98 ff.). I det omfångsmässigt starkt varierade material som värdegrundstexterna är blir det mindre meningsfullt att göra kvantifieringar, men man kan konstatera att många ord är svåra att relatera till ett konkret sammanhang. Orden i sig uppfattas knappast som svåra, och är knappast tekniska, men har alltså oklar referens. I Socialstyrelsens värdegrund förekommer till exempel fraserna "viktiga frågor", "rätt kvalitet" och "bästa resultat". Polisen "skapar förtroende genom att vara engagerade med ansvar och respekt". Men det framgår inte av den här texten hur engagemanget och respekten kommer till uttryck, och vad Polisen tar ansvar för. Resultatet blir att enstaka satser kan förefalla helt tömda på innehåll, som "[v]i prioriterar och slutför vårt arbete med rätt kvalitet”. 


\section{Upprepning med variation}

Det vanligaste ordet i alla tre texterna är och. Förekomsten är knuten till det återkommande stildraget att kombinera fraser parvis, tydligast i skolans värdegrund. Så här kan det se ut: "Skollagen slår fast att utbildningen inom skolväsendet syftar till att elever ska inhämta och utveckla kunskaper och värden", "En viktig uppgift för skolan är att ge överblick och sammanhang" (Skolan), "Vi prioriterar och slutför vårt arbete med rätt kvalitet", "Vi samarbetar och använder oss både av varandras och andras kunskaper för bästa resultat" (Socialstyrelsen), "Polisens uppdrag är att öka tryggheten och minska brottsligheten" (Polisen). Som framgår av exemplen förekommer samordning av olika satsdelar och fraskonstruktioner. Effekten av stildraget är att texterna ger intryck av att textens avsändare sökt att täcka in alla tolkningsmöjligheter.

\section{Språkhandlingar}

Modalitetsmässigt är det stor skillnad mellan de tre texterna. I skolans värdegrund är förpliktelsemodalitet (Holmberg 2011) vanligt förekommande (mina kursiveringar):

Eleven $s k a$ i skolan möta respekt för sin person och sitt arbete. Skolan ska sträva efter att vara en levande social gemenskap som ger trygghet och vilja och lust att lära.

I fallet med skolans läroplan är det tydligt att texten är avsedd att läsas som direktiv. Här talar avsändaren (Skolverket) om för de lokala skolmyndigheterna hur skolverksamheten ska fungera. Detta uttrycks inte bara genom den starka förpliktelsemodaliteten i texten, utan också av textens placering först i läroplanen, som är ett styrdokument för skolan.

De båda andra värdegrunderna innehåller huvudsakligen påståendesatser utan modalitet, med $\ddot{a} r$ som det vanligaste finitet i texterna:

Vi är sakliga. Vårt arbete $\ddot{a} r$ rättssäkert och bygger på vetenskap och beprövad erfarenhet. Vi förmedlar enhetliga budskap och redovisar öppet grunderna för våra ställningstaganden och beslut. (Socialstyrelsen)

Den typ av struktur som visas i citatet ovan är typisk för flera av de svenska myndigheternas värdegrundstexter. Subjektet i satsen - som gärna står först - är vi, och ska tänkas stå för medarbetarna i organisationen. Satserna är påståendesatser, oftast utan modalitet, där finitet uttrycker ett befintligt läge: vi är, vi förmedlar, vi redovisar. Det här sättet att skriva policy bekräftar vad Ahmed (2007) skriver om de engelska högskolornas antidiskrimineringspolicy. Texten uttrycker att läget är gott och inbjuder inte till att diskutera vad som kan göras.

De granskade värdegrundstexterna är också goda exempel på att det som avviker i form mot den övriga texten framstår som markerat. I skolans värdegrund, som har så tydlig förpliktelsemodalitet, framstår satserna utan modalitet som mera synliga: 
Medvetenhet om det egna och delaktighet i det gemensamma kulturarvet ger en trygg identitet som är viktig att utveckla tillsammans med förmågan att förstå och leva sig in i andras villkor och värderingar. Skolan $\ddot{a} r$ en social och kulturell mötesplats som både har en möjlighet och ett ansvar för att stärka denna förmåga hos alla som arbetar där.

Att den beskrivna medvetenheten ger en trygg identitet, och att skolan är en social och kulturell mötesplats, framställs här som en realitet. Mot bakgrund av textens rika förekomster av direktiv är konstruktionen iögonenfallande. Men direktivet finns här i den bisats som avslutar den sista meningen i citatet (kursiverad). Ett mera direkt sätt att uttrycka detta hade varit att skriva "Skolan ska stärka förmågan att leva sig in i andras villkor och värderingar", men det är ett återkommande drag i texten att skjuta det som inte är öppet för förhandling långt till höger i satserna. I det här materialet framstår det som ett särdrag för skolans värdegrund.

Svårigheten att tolka adressiviteten i språkhandlingar utan modalitet har behandlats av Hamberg (2011), som studerat just ett policydokument för skolan. Hon konstaterar att textens mottagare kan skifta beroende på hur språkhandlingarna uppfattas: som påstående, uppmaning eller erbjudande (s. 141). När Socialstyrelsen skriver "Vi är lyhörda för våra målgruppers behov" kan det läsas som ett erbjudande för medborgarna som är just målgruppen, samtidigt som formuleringen kan uppfattas som en uppmaning för de anställda. Texterna blir på så vis dokument som är öppna för interpersonell förhandling.

\section{Värdegrundstexter - en hybrid genre?}

Med utgångspunkt i en genredefinition där genre förstås som kopplad till en återkommande social situation (Ledin 1999, s. 23 f.) kan värdegrundstexterna förstås som representanter för en genre. Denna genre är dock relativt ny och söker både sin form och sin plats i myndigheternas textvärld. Värdegrundernas roll i en textvärld stadd i snabb förändring är en förklaring till att texterna är så olika varandra. De värdegrunder som är aktuella här skiljer sig från varandra både när det gäller publikationskanal och språklig utformning, i alla fall utifrån de aspekter som undersökts här. Ett gemensamt drag verkar dock vara att värdegrundstexten placeras "mitt i verksamheten"; den ska alltså vara ett levande dokument som kan diskuteras och vara till nytta i olika sammanhang. Ett radikalt, men möjligen inte ovanligt, exempel på detta har jag sett på ett äldreboende, där värdegrunden - i form av ord på lappar - fanns upphängd på ett träd $\mathrm{i}$ vestibulen.

Som myndighetstext skiljer sig värdegrunden från flera andra typer av texter genom att den har tydligt intertextuellt släktskap med andra texter än myndighetstexter. På lexikal nivå, med många värdeladdade ord och många ord utan konkret referens, påminner texten om marknadsföringstexter ${ }^{9}$. Också visionstexterna (Waaranperä 2013) ligger lexikalt nära marknadsföringstexterna. Ett dilemma både för läsare och textskapare kan alltså vara att skilja

\footnotetext{
${ }^{9}$ Se t.ex. Korpus (2008) som i sin undersökning av prisbelönta svenska annonser konstaterar att annonsretoriken kan ha "gott om positivt konnoterade ord" (2008, s. 284). I Korpus refereras också Ledin (2000) som i en undersökning av annonsers språk i veckopressen finner att explicit argumentation kan ersättas av hyperboliska formuleringar (Korpus 2008, s. 45 f.).
} 
visionstexter och värdegrundstexter från varandra. För läsare kan det därtill vara svårt att skilja dessa texter från kommersiella marknadsföringstexter.

Jag menar att man kan betrakta värdegrundstexterna huvudsakligen som ett verktyg för att skapa en anda inom en myndighet. Initiativet, och direktivet, kommer då från myndighetens ledning. Detta blir tydligt i Socialstyrelsens värdegrund, där den textuella inramningen konstruerar ledningen som avsändare. Mindre tydligt är det hos Polisen, där texten på webbplatsen talar om hur värdegrunden arbetats fram i medarbetardialog. För skolans värdegrund är det regeringen som har initiativet och som agerar via Skolverket. Texternas verktygsfunktion hör hemma i en managementkultur där det gäller att få medarbetarna att känna stolthet över att tillhöra en enhet som är effektiv och som handlar rätt.

Av de tre texter som behandlats här är det skolans värdegrund som avviker mest från de övriga värdegrundstexter som finns vid svenska myndigheter. De båda övriga myndigheternas värdegrunder förefaller vara hybrider av de privata företagens mission statements, ett slags fusioner där managementtänkande möter myndighetskultur. I det sammanhanget är det oväntat att så många myndigheter valt att låna benämningen för detta slags text från skolan, för det är faktiskt bara till benämningen som texterna liknar varandra. En möjlig förklaring till detta förhållande är att det är ordet värdegrund som blivit spritt, delvis genom den debatt som uppstod på 1990-talet om delar av skolans värdegrund. Skolans värdegrund som textmönster verkar inte ha påverkat värdegrunder utanför skolan.

\section{Kan värdegrundstexterna innebära klarspråksproblem?}

Vid många svenska myndigheter idag är medvetenheten om klarspråksfrågor hög. Vissa av klarspråksråden (Klarspråk 2010) är vid dessa myndigheter väl kända, såsom vikten av grafisk reda, att ord och meningar inte får vara för långa samt att meningarna gärna får vara högertunga (dvs. att finitet ska komma tidigt i den första fria satsen). De värdegrundstexter som studerats här kan sägas vara representanter för en myndighetskultur som känner igen och respekterar klarspråksråden: texterna är grafiskt välorganiserade, med ganska korta meningar (i genomsnitt mellan 9,5 och 17 ord), även om variationen i meningslängd i skolans värdegrund är ganska stor.

En text kan dock vara svår att ta till sig trots att de grundläggande klarspråkskraven är uppfyllda. En av klarspråksverksamhetens grundfrågor är om mottagaren kan göra det den förväntas efter att ha läst texten (jfr Nyström Höög 2012, s. 38). Det är inte självklart att det förhållandet gäller för värdegrundstexterna, eftersom det är oklart dels vem som är mottagare, dels vad denna förväntas göra med den lästa texten. För medarbetaren kan texterna vara problematiska, eftersom de faktiskt reglerar förväntningar på ett visst beteende. För medborgarens del kan texterna förväntas reglera förväntningarna på myndigheten. På så sätt förstärker de här texterna möjligen kundidentiteten hos medborgaren i relation till myndigheten.

På syntaktisk nivå är de här texterna inte problematiska; de har genomgående korta meningar. Ett drag i skolans värdegrund har dock väckt mitt intresse. Den texten har genomgående stark högertyngd i meningarna. En viss högertyngd brukar rekommenderas i klarspråkssammanhang. I min analys av skolans värdegrund har jag dock kunnat konstatera att detta också får till följd att påståenden som inte är öppna för förhandling skjuts långt till höger 
i meningen och inte presenteras $\mathrm{i}$ form av fria satser, som i följande exempel med flera infinitivkonstruktioner:

Skolans uppgift är att låta varje enskild elev finna sin unika egenart och därigenom kunna delta i samhällslivet genom att ge sitt bästa i ansvarig frihet.

Här är ett tänkbart responsdrag “ja (nej), det är (inte) skolans uppgift att låta eleverna finna sin unika egenart". Det ligger däremot inte nära till hands att ge responsen "nej, jag menar inte att deltagande i samhällslivet förutsätter att man funnit sin unika egenart". Den premissen är presupponerad, och placerad för långt ifrån den del av satsen som uttrycker själva språkhandlingen, för att läsaren ska uppfatta premissen som öppen för dialog. Det här draget i texten gör att högertyngden faktiskt kan vara bedräglig. Om den innebär att premisser för påståenden i texten presenteras på en plats där de blir mindre synliga, då måste råden om vänster- och högertyngd möjligen modifieras och göras mindre generella. Det vore därför värdefullt att få undersökt vad läsare uppfattar som utsagt respektive underförstått i sin läsning, och hur det hänger samman med position i satsen.

En svårighet kan också ligga i mängden värdeladdade ord utan konkret referens. Det är helt enkelt svårt att veta hur den kontext ska se ut där en viss värdegrundstext blir meningsfull. Den sortens meningstomhet kan vara en viktig förklaring till den kritik som uppstått mot Polisens värdegrundsarbete ("Polisens värdegrundsarbete döms ut", 2013). Det kan leda till att texterna avfärdas som meningslösa och innehållslösa.

\section{Slutord}

I den här presentationen av svenska myndigheters värdegrundstexter har jag velat visa en framväxande genre och hur den förhåller sig till andra myndighetstexter. Värdegrundstexterna kan ses som ett uttryck för en föränderlig textkultur vid svenska myndigheter, där kanske allt flera texter inte tar sikte på vare sig att informera om myndighetens verksamhet eller att genomföra ett myndighetsbeslut. Värdegrundstexternas syfte är i stället dels att vara verktyg för styrning av myndighetens personal, dels att ge ett slags löfte till de medborgare som har ärenden till myndigheten om en viss kvalitet. Det här dubbla syftet med texterna gör att det inte är alldeles enkelt att förstå vem som är avsändare till texten och vem som är primär mottagare. En anställd vid en myndighet kan ju till exempel ses både som avsändare och mottagare. Det gör vissa klarspråksråd komplicerade i förhållande till värdegrundstexterna. Vad innebär det här att tänka på mottagaren? Och hur bearbetar man texterna till en begriplighetsnivå där mottagaren säkert vet vad den ska göra efter att ha läst texten, om man kanske inte ska göra något alls?

Den språkliga analysen av texterna visar att värdegrunderna knappast är problematiska ur klarspråksperspektiv, även om mängden abstrakta ord kan göra texterna svåra att utvinna konkret information ur. För den som arbetar utifrån klarspråkets principer är de därför kanske inte så angelägna att intressera sig för. Jag menar dock att värdegrundstexterna är intressanta ur ett språkvårdsperspektiv, och det av två skäl. 
Det första skälet gäller den kostnad, i form av arbetstid och lästid, som de här texterna genererar. Ett tungt vägande argument för klarspråksinsatser brukar vara att de sparar tid, i form av arbetstid hos myndigheten. I det sammanhanget talar man ofta om textlängd och att det är bra att inte skriva längre än nödvändigt. Men om man vill spara tid är också textmängd relevant. Om en läsare, vare sig denna finns inom myndigheten eller utanför, behöver arbeta sig igenom stora textmängder för att förstå avsändarens intention, då kan textmängden i sig bli ett begriplighetshinder. Värdegrundstexterna ökar myndigheternas textrepertoar och därmed mängden texter, och ett rimligt uppdrag för myndighetsspråkvården kan vara att diskutera vilka texter som behövs, för vilka avsändare och för vilka mottagare, och vilka som kan gallras bort eller publiceras på mindre allmänt tillgängliga platser än myndigheternas webbplatser. Ett klarspråksråd i en tid där mängden texter blir större och större skulle kunna vara "Fråga alltid om texten behövs. Och i så fall för vem den behövs." Färre texter gynnar både samhällsekonomin och den medborgare som vill förstå en myndighet.

Det andra skälet gäller frågan om vilka texter som ska omfattas av klarspråksuppdraget. Det framgår nog i den här artikeln att begreppet klarspråk är ganska plastiskt, och kan användas på lite olika sätt. Men man kan återvända till den ideologiska utgångspunkt som faktiskt finns för klarspråkstanken; den innebär en strävan mot att medborgare enkelt ska kunna förstå myndigheternas texter för ett demokratiskt och rättssäkert samhälle. Utifrån den utgångspunkten innebär värdegrundstexterna - och även andra texter med syfte att synliggöra den egna myndigheten - faktiskt inte ett klarspråksproblem. Ingen medborgare kommer att få problem med sin kontakt med myndigheten för att den här typen av policytext inte är tillräckligt välformulerad. Kanske ska vi som värnar klarspråkstanken därför se värdegrundstexterna som en välkommen möjlighet att problematisera och snävra in klarspråksbegreppet, att stänga ute vissa texter, för att på så vis vinna en skarpare avgränsad och tydligare verksamhet.

Personligen tycker jag att man kan ha många kritiska synpunkter på den typ av policytexter som värdegrundstexterna representerar. Inte minst är det allvarligt med texter som skapas bara för att de ska finnas där, och kanske inte läses eller används alls. Om de i sämsta fall också bidrar till att problem skrivs fram som icke-existerande, vilket Ahmeds (2007) forskning ju verkar peka på, då är det riktigt illa. Och den här typen av texter verkar snarast tillta i mängd. Därför kan det finnas skäl att diskutera de här texternas existens utifrån vad de gör med skattemedel och för förtroendet för myndigheters texter. Det är dock inte nödvändigtvis en klarspråksdiskussion. I den diversifierade textkultur som växer fram vid dagens svenska myndigheter är det kanske dags för en myndighetsspråkvård, eller ännu hellre en myndighetstextvård, som bland annat omfattar klarspråk.

\section{Litteratur}

Ahmed, S. (2007). 'You end up doing the document rather than doing the doing': Diversity, race equality and the politics of documentation. Ethnic and Racial Studies, 40(3), 590-609.

Augustsson, F. (2004). Webbsidor som visuella uttryck. I P. Aspers, P. Furhere \& A. Sverrisson (Red.), Bild och samhälle (s. 139-159). Lund: Studentlitteratur.

Boltanski, L. \& Thévenot, L. (2006). On Justification: Economies of Worth. Princeton: Princeton University Press.

Etisk plattform på plats inom vård och omsorg. Hämtad 13 januari 2014 från http://www.regeringen.se/sb/d/17063/a/224560 
Examples of Mission Statements. Hämtad 28 januari 2014 från http://examples.yourdictionary.com/examples/examples-of-mission-statements.html

Fredriksson, M. \& Pallas, J. (2013). Med synlighet som ledstjärna. En analys av vilka principer som styr kommunikationsarbetet $i$ nationella förvaltningsmyndigheter. (Division of Media and Communication Science Research Report 2013:1.) Uppsala: Uppsala universitet.

Hamberg, L. (2011). Alternativa läsarroller i en arbetsplan. Språkhandlingar ur läsarperspektiv. I P. Holmberg, A.-M. Karlsson \& A. Nord (Red.), Funktionell textanalys (s. 139-151). Stockholm: Norstedts.

Hanell, L. (2012). Texten på webben - mellan myndighet och medborgare. I: Nyström Höög, C., Söderlundh, H. \& Sörlin, M. (Red.), Myndigheterna har ordet. Om kommunikation i skrift (s. 105-122). Stockholm: Språkrådet och Norstedts.

Holmberg, P. (2011). Texters interpersonella grammatik. I P. Holmberg, A.-M. Karlsson \& A. Nord (Red.), Funktionell textanalys (s. 97-113). Stockholm: Norstedts.

Holmberg, P. \& Karlsson, A.-M. (2006). Grammatik med betydelse. En introduktion till funktionell grammatik. (Ord \& stil. Språkvårdssamfundets skrifter 37.) Uppsala: Hallgren \& Fallgren.

“Internatelever brändes med strykjärn”. I Svenska Dagbladet 27/8 2013. Hämtad 13 januari 2014 från http://www.svd.se/nyheter/inrikes/internatelever-brandes-med-strykjarn 8455638.svd

Klarspråk-för en vårdad, enkel och begriplig svenska. (2010). Folder Språkrådet. Hämtad 14 januari 2014 från www.sprakradet.se

KORP (2013). Språkbanken, Göteborgs universitet. Hämtat 3 september 2013 från http://spraakbanken.gu.se/korp

Korpus, E. (2008). Reklamiska. Guldäggsannonser 1975-2007. (Studier från Örebro i svenska språket 3.) Örebro: Örebro universitet.

Koskela, M. (2013). Same, same, but different. Intertextual and Interdiscursive Features of Communication Strategy Texts. Discourse \& Communication, 7(4), 389-407.

Ledin, P. (1999). Texter och textslag - en teoretisk diskussion. (Rapporter från projektet Svensk sakprosa 27.) Lund: Institutionen för nordiska språk.

Ledin, P. (2000). Veckopressens historia. Del II. (Rapporter från projektet Svensk sakprosa 29.) Lund: Institutionen för nordiska språk, Lunds universitet.

Ledin, P. \& Selander, S. (2003). Institution, text och genre. I: B. Englund \& P. Ledin (Red.), Teoretiska perspektiv på sakprosa (s. 91-122). Lund: Studentlitteratur.

Lpo 94 = 1994 års läroplan för det obligatoriska skolväsendet. SKOLFS 1994:1. Stockholm: Skolverket.

Lgr 11 = Läroplan för grundskolan, förskoleklassen och fritidshemmet 2011. SKOLFS 2010:37. Stockholm: Skolverket.

Nyström, C. (2001). Hur hänger det ihop? En bok om textbindning. (Ord och stil. Språkvårdssamfundets skrifter 32.) Uppsala: Hallgren \& Fallgren.

Nyström Höög, C. (2012). Beslut och informerande texter 2001 och 2011. I: C. Nyström Höög, H. Söderlundh \& M. Sörlin (Red.), Myndigheterna har ordet. Om kommunikation i skrift (s. 72-104). Stockholm: Språkrådet och Norstedts.

Nyström Höög, C. (2014). Texter som bygger strukturer. Om värdegrunder och andra anspråksfulla texter. Föredrag vid Svenskans beskrivning 34. Lund 22 oktober 2014.

Nyström Höög, C., Söderlundh, H. \& Sörlin, M. (Red.) (2012). Myndigheterna har ordet. Om kommunikation $i$ skrift. Stockholm: Språkrådet och Norstedts.

Polisens värdegrund. Hämtad den 15 september 2013 från http://polisen.se/Om-polisen/Uppdrag-och-mal/Ny-vardegrund-utgar-fran-medarbetarna

"Polisens värdegrundsarbete döms ut”. I Dagens Nyheter 29/9 2013. Hämtad 9 februari 2014 från http://www.dn.se/nyheter/sverige/polisens-vardegrundsarbete-doms-ut

Pollitt, C. \& Bouckaert, G. (2011). Public Management Reform. A Comparative Analysis: New Public Management, Governance and the Neo-Weberian State. Oxford: Oxford University Press.

Regeringsformen. SFS 1974:152. Hämtad den 4 november 2013 från http://www.riksdagen.se/sv/Dokument-Lagar/Lagar/Svenskforfattningssamling/Kungorelse-1974152om-beslu_sfs-1974-152

Rehnberg, H. S. (2014). Organisationer berättar. Narrativitet som resurs i strategisk kommunikation. (Skrifter utgivna av Institutionen för nordiska språk vid Uppsala universitet 90.) Uppsala: Uppsala universitet.

Sarangi, S. \& Slembrouck, S. (1996). Language, Bureaucracy and Social Control. London: Longman.

“Skolinspektionen stänger Lundsberg”. I Dagens Nyheter. Hämtad 18 januari 2014 från http://www.dn.se/nyheter/sverige/skolinspektionen-stanger-lundsberg

Skolinspektionens beslut om Lundsbergs skola. Hämtad 3 januari 2014 från http://www.skolinspektionen.se/Documents/Rapporter/2013/07-08-juli-augusti/beslut-lundsbergsskola.pdf 
Socialstyrelsens värdegrund. Hämtad 18 november 2013 från

http://www.socialstyrelsen.se/omsocialstyrelsen/arbetahososs/Documents/Socialstyrelsensvardegrund-2012.pdf

SOU 1992:94. Skola för bildning, huvudbetänkande av Läroplanskommittén. Stockholm: Allmänna förlaget. Språket i lagar och andra författningar (1967). PM från Statsrådsberedningen 25/1/1967. Stockholm. Språklagen. SFS 2009:600. Hämtad 18 november 2013 från http://www.språkrådet.se/språklagen Språkrådets uttolkning av Språklagen (2010). Hämtad 18 november 2013 från http://www.språkrådet.se/uttolkning-språklagen

Söderlundh, H. \& Sörlin, M. (2014). Myndighet och privatpersoner i dialog på Facebook. En analys av positioneringar och receptionsroller på Försäkringskassans Facebooksida Förälder. I: J. Lindström, S. Henricson, A. Huhtala, P. Kukkonen, H. Lehti-Eklund \& C. Lindholm (Red.), Svenskans beskrivning 33. Förhandlingar vid Trettiotredje sammankomsten för svenskans beskrivning. Helsingfors den 1517 maj 2013 (s. 459-469). Helsingfors: Helsingfors universitet.

Waaranperä, U. (2013). Visionära verk? En kartläggning av svenska myndigheters visionsformuleringar. (Scores rapportserie 2013:4.) Stockholm: Stockholms centrum för forskning om offentlig sektor.

Winther Jørgensen, M. \& Phillips, L. (2000). Diskursanalys som teori och metod. Lund: Studentlitteratur. 